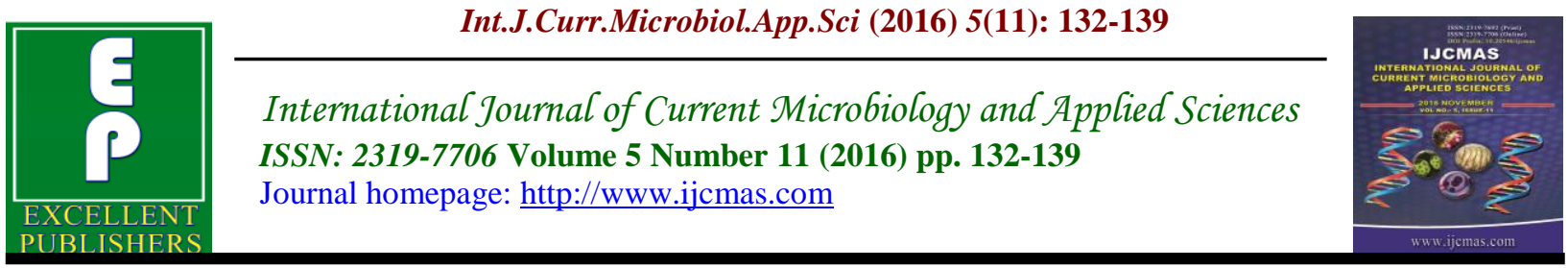

Original Research Article

http://dx.doi.org/10.20546/ijcmas.2016.511.015

\title{
Role of Alginate and Oxalic acid in Ameliorating Se Toxicity in Hapalosiphon cyanobacterium
}

\author{
Rachana B. Chavan ${ }^{1}$ and Meenakshi B. Bhattacharjee ${ }^{1,2 *}$ \\ ${ }^{1}$ Laboratory of Algal Biotechnology, Department of Bioscience \\ Barkatullah University, Bhopal 462026 (M.P), India \\ ${ }^{2}$ Department of Biosciences, Rice University, Houston TX 77088 USA \\ *Corresponding author
}

\section{Keywords}

Hapalosiphon sp., chelating agent, selenium alginate, oxalic acid, immobilization.

\section{Article Info}

Accepted:

04 October 2016 Available Online: 10 November 2016

\section{A B S T R A C T}

Environmental pollution with toxic metals is a quickly growing serious problem for humanity and also a major threat to our planet. The problems effecting the environment are diverse and approaches to find solutions are often intimately connected with modern or classical methods of biotechnology. In this connection unique ability of microorganism especially cyanobacteria to tolerate and accumulate metal toxicity from the environment have made them an active research subject in the past few years. With this aim the present study is an attempt to investigate the effect of selenium on rice field cyanobacterium Hapalosiphon sp., when selenium(Se) reach to the rice field ecosystems through the sources of irrigation by simulating a similar situation in the laboratory. This paper discusses the role of alginate with which the algal cells have been immobilized and oxalic acid in reducing selenium toxicity in Hapalosiphon. The study revealed that the cell immobilization with Calcium alginate could protect the growth and nitrate reductase (NR) activity of the organism as compared to free cells against the toxicity of selenium at 200ppm (LC-50). Use of oxalic acid as a chelator greatly reduced the toxicity of selenium in the culture, improved growth and NR activity as compared to the controls. As naturally immobilized consortiums of cyanobacteria are a common occurrence in rice fields. This study indicates that presence of high concentrations of Se in these ecosystems may not have an adverse effect on the algal growth and enzyme activities as well as the rice plants.

\section{Introduction}

Industry based life style of our current world has led to sudden rise in anthropogenic impact on the biosphere in the form of pollution. Environmental pollution with toxic metals due to human activities is a matter of serious concern in industrialized nations, due to their incremental accumulation in food chain and continued persistent in the aquatic and terrestrial ecosystem (Chen and Pan, 2005; Banerjee et al., 2008). Metals occur as natural components of the earth's crust and constitute about $75 \%$ of the known element, and are persistent environmental contaminants since they cannot be degraded 
nor destroyed (Banerjee and Yadav, 2009). About thirteen trace metals and metalloids include $\mathrm{Ag}, \mathrm{As}, \mathrm{Be}, \mathrm{Cd}, \mathrm{Cr}, \mathrm{Cu}, \mathrm{Hg}, \mathrm{Ni}, \mathrm{Pb}$, $\mathrm{Sb}, \mathrm{Se}, \mathrm{Ti}, \mathrm{Zn}$ are considered as priority pollutants (Spark, 2005; Gadd, 2010). They originate from natural sources like rocks and metalliferous minerals, and anthropogenic inputs such as agriculture, metallurgy, energy production, microelectronics, mining, sewage sludge and waste disposal (Landa, 2005; Gilmour and Riedel, 2009; Gadd, 2010). One such toxic metal is selenium which is generally released into the environment due to their wide application in electronics industry, in the manufacture of paints, glass, ceramic, metal alloys, rectifiers, fungicides and pesticides formulation.

Now over the past two decades, selenium has been identified as a major environmental contaminant released into the environment through various industrial processes, modern agricultural practices and human activities which is non-degradable and has strong potential to bio-accumulate in toxic level in the environment. Selenium toxicity is a problem of increasing significance for ecological, evolutionary and environmental reasons. It is a regulatory problem and assuming increasing importance due to increased evidence for selenium contamination of the lentic systems which are more at risk of selenium poisoning such as rice fields than the lotie systems (Chapman, 2000; Chouhan and Banerjee, 2010). As a result, Selenium has emerged as an important environmental issue and has gained the attention of environmentalists around the world. There are a number of methods available for the removal of metal from the environment, but these are so expensive, ineffective and not eco-friendly (Gupta et al., 2000; Kretschmer et al., 2003). In this context, unique ability of cyanobacteria to tolerate and accumulate metal toxicity from the environment has made them an active research subject in the past few years. Inspired by such consideration present study is an attempt to investigate the effect of selenium on growth and nitrate reductase activity of free and immobilized cells of rice field cyanobacterium Hapalosiphon sp. when selenium reached to the rice field through different pollution sources. Additional role of chelating agent has also been studied to mitigate the selenium toxicity.

\section{Materials and Methods}

During the early phase of this work, filamentous cyanobacterium Hapalosiphon $s p$. was collected and isolated from rice fields of Sehore M.P. Identification of cultures was done with the aid of available taxonomic keys (viz Geitler, 1932; Desikachary, 1959; Rippka et al., 1979). The cloning and purification was done with the aid of standard microbiological techniques. Cultures were grown axenically in BG-11 medium and maintained at $25 \pm 2^{\circ} \mathrm{C}, 2500-3000$ Lux light intensity and 14:10 hour light and dark rhythm.

Selenium solutions with different concentrations were prepared by dissolving selenium dioxide $\left(\mathrm{SeO}_{2}\right)$ in different required quantities into the $\mathrm{BG}-11$ medium and were filtered with $0.45 \mu$ Millipore filter. The sublethal (200ppm) and lethal (250ppm) value of selenium treated algae were determined by standard plate/colony count method with an exposure time to the metal equivalent to the generation time of the organism.

Immobilization was done by cell entrapment method using calcium alginate beads as described by Singh et al., 1989. Growth and nitrate reductase activity of cyanobacteria was studied in free cells and immobilized 
cells and compared. Growth measurement was done by chlorophyll-a extraction in $100 \%$ methanol and optical density read in a spectrophotometer at $665 \mathrm{~nm}$. The amount of Chl- $a$ extracted was calculated according to the equation of Mackinney (1941). The estimation of in vivo nitrate reductase activity was measured by the method of Camm and Stein (1974) as slightly modified by Kumar and Kumar (1980).

Toxicity mitigating studies: The amelioration of selenium toxicity was studied with chelating agent i.e. oxalic acid. The chelating agent (Oxalic acid) was added in different concentrations to the medium i.e. $1 \%, 5 \%$ and $10 \%$. Best results were obtained in $5 \%$ oxalic acid and therefore shown in this study.

All chemicals analar grade with highest purity level were obtained from British Dry House (Glaxo) Mumbai. The culture medium and culture vessels were sterilized at 15 $\mathrm{lb} /$ inch $^{2}$ pressure at $121^{\circ} \mathrm{C}$ for 15 minutes, and chemicals were sterilized through millipore filter with a pore size of $0.45 \mu \mathrm{m}$.

Statistical analysis: The analysis consists of mean values and standard deviations that are given in graphs. Means were compared using student- $\mathrm{t}$ test at $\alpha=0.01$ and 0.05

\section{Result and Discussion}

The growth of Hapalosiphon was significantly inhibited with the increasing concentration of metal selenium. The study revealed that sublethal concentration (LC-50 value) of the organism for selenium was 200ppm whereas, the lethal concentration (LC value) of selenium was found to be $250 \mathrm{ppm}$. A comparative growth curve of free and immobilized cells of Hapalosiphon with and without Se treatment showed increasing trend till $72 \mathrm{~h}$ after which the growth was declined
(Fig-1). Further, it was observed that immobilization has significant protective effect on growth of Hapalosiphon against the toxicity of metal at sublethal concentrations of Se i.e. 200ppm. But no significant protection was obtained with lethal concentration of Se i.e. $250 \mathrm{ppm}$.

The growth was also studied with different concentrations $(1 \%, 5 \%$ and $10 \%)$ of chelating agent i.e. oxalic acid in free and immobilized cells of Hapalosiphon (Table-1). The maximum stimulation in growth was noted in $5 \%$ of oxalic acid in Selenium treated free and immobilized cells. In Selenium nontreated cells, addition of $5 \%$ oxalic acid showed no significant increase in growth rate in free and immobilized cells as compared to control cells (without added oxalic acid) that was $17.4 \%$ and $22.6 \%$ respectively at $72 \mathrm{~h}$ $(\mathrm{P}=>0.05)$. Addition of $5 \%$ oxalic acid produced significant increase in growth rate at $200 \mathrm{ppm}$ Selenium treated cells to $31.6 \%$ and $36.6 \%$ in free and immobilized cells respectively over the control cells (without added oxalic acid) at $72 \mathrm{~h}(\mathrm{P}=>0.05)$. In case of $250 \mathrm{ppm}$ Selenium treated cells, a decline was observed and there was $10.8 \%$ and $7.8 \%$ decrease in the growth rate in free and immobilized cells respectively as compared to control cells (without added oxalic acid) at 72 $\mathrm{h}(\mathrm{P}=>0.05)$. Fig-2 shows the percentage increase in the growth of free and immobilized cells of Hapalosiphon in oxalic acid $(5 \%)$ at $72 \mathrm{~h}$.

Nitrate reductase activity of Hapalosiphon in free and immobilized cells with and without Se treatment was also studied. Maximum nitrate reductase activity for the organism was observed at $48 \mathrm{~h}$ after which the nitrate reductase activity was declined (Fig-3). In this study an interesting observation was that the enzyme activity in Se treated free and immobilized cells was substantially increased as compared to without Se treated free and 
immobilized cells. Further, immobilization enables Hapalosiphon to not only overcome the toxicity but also to enhance nitrate reductase activity when exposed to 200ppm.

The nitrate reductase activity of Hapalosiphon with different concentration $(1 \%, 5 \% \& 10 \%)$ of chelating agent i.e. Oxalic acid was also studied (Table-2). The best results in ameliorating Selenium toxicity obtained with $5 \%$ oxalic acid. In general, addition of oxalic acid to Selenium treated free and immobilized cells produced significant amelioration of the toxicity. In case of Selenium non-treated cells, there was no significant increase in the nitrate reductase activity with the addition of $5 \%$ oxalic acid and the increase was $22.4 \%$ and $25.7 \%$ in free and immobilized cells of Hapalosiphon respectively as compared to control cells (without added oxalic acid) at 48 hours $(\mathrm{P}=>$ $0.01)$. Whereas, addition of $5 \%$ oxalic acid in $200 \mathrm{ppm}$ Selenium treated cells showed $35.8 \%$ and $40 \%$ increase in nitrate reductase activity in free and immobilized cells respectively as compared to control cells (without added oxalic acid) at 48 hours $(\mathrm{P}=>$ 0.05). In lethal concentration $250 \mathrm{ppm}$, addition of 5\% oxalic acid showed no significant increase in nitrate reductase activity and that was $9.6 \%$ and $12.9 \%$ in Selenium treated free and immobilized cells respectively over the control cells (without added oxalic acid) at 48 hours ( $\mathrm{P}=>0.01)$.Fig4 shows the percentage increase in the nitrate reductase activity of free and immobilized cells of Hapalosiphon in oxalic acid (5\%) at $48 \mathrm{~h}$.

The observations in the present study clearly indicate that in all conditions immobilized Hapalosiphon cells showed great potential to ameliorate selenium toxicity when compared to free cells. However the growth reduction in Se treated free cells (Fig-1) could be due to the fact that small amount of selenium reaching inside the cell may be influencing some enzymes or pathways, thereby reducing the growth. On the other hand in immobilized cells the calcium alginate chelates the metal on the surface of the bead not allowing it to enter in quantities that could make a difference.

In contrast to growth, Se treated free and immobilized cells of Hapalosiphon gave the highest nitrate reductase activity than without Se treated free and immobilized cells (Fig-2). This could be due to the fact that selenium is of metabolic importance in cyanobacteria, being involved in formation of various selenoamino acids and proteins. The nutritional requirement for selenium is derived from the fact that several microbial enzymes are also selenium dependent and involves selenium-containing amino acids analogue of cysteine, selenocysteine. Maximum NR-activity in sublethal doses is probably because this concentration of selenium does not affect the enzymes of the chlorophyll biosynthetic pathway allowing chlorophyll to be synthesized and hence photosynthesis. Since the reductant and ATP required for nitrate reductase activity is photosynthetically derived therefore the observed results.

The observed protection due to calcium alginate immobilization on chlorophyll- $a$ content (growth) and nitrate reductase activity at $200 \mathrm{ppm}$ of selenium could be due to the metal binding capacity of alginate. Alginate, which is a mixture of polyguluronic acid and polymannuronic acid, has abundant hydroxyl groups which bind the metal ions and prevent them from entering the cells in full concentration thereby protecting against the decrease of chlorophyll- $a$ content and enzyme activities as observed in free cells. Banerjee and Mishra, 2002 have also shown the mitigating effect of immobilization on cyanobacteria subjected to toxic metal stress. 
Table.1 Shows the effect of chelating agent (oxalic acid) on the growth of free and immobilized cells of Hapalosiphon sp. at 72h. FC -Free cells. IC- Immobilized cells.

\begin{tabular}{|l|l|l|l|l|l|l|}
\hline \multirow{3}{*}{\begin{tabular}{c} 
Conditions \\
\cline { 2 - 7 }
\end{tabular}} & $\begin{array}{l}\text { Gapalosiphon(without } \\
\text { Selenium) }\end{array}$ & $\begin{array}{l}\text { Hapalosiphon+200ppm } \\
\text { Selenium }\end{array}$ & $\begin{array}{l}\text { Hapalosiphon+250ppm } \\
\text { Selenium }\end{array}$ \\
\cline { 2 - 7 } & FC \pm SD & IC \pm SD & FC \pm SD & IC \pm SD & FC \pm SD & IC \pm SD \\
\hline Control & $1.516 \pm 0.06$ & $1.617 \pm 0.06$ & $1.730 \pm 0.06$ & $1.932 \pm 0.09$ & $1.162 \pm 0.05$ & $1.288 \pm 0.04$ \\
\hline 1\% oxalic acid & $1.629 \pm 0.06$ & $1.718 \pm 0.07$ & $1.756 \pm 0.09$ & $1.806 \pm 0.08$ & $1.288 \pm 0.04$ & $1.377 \pm 0.04$ \\
\hline 5\% oxalic acid & $1.781 \pm 0.07$ & $1.983 \pm 0.11$ & $1.996 \pm 0.11$ & $2.210 \pm 0.13$ & $1.351 \pm 0.04$ & $1.490 \pm 0.06$ \\
\hline $10 \%$ oxalic acid & $1.314 \pm 0.03$ & $1.389 \pm 0.05$ & $1.478 \pm 0.06$ & $1.553 \pm 0.06$ & $1.225 \pm 0.01$ & $1.263 \pm 0.02$ \\
\hline
\end{tabular}

(Results mean \pm S.D, $n=3$ )

Table.2 Shows the effect of chelating agent (oxalic acid) on the nitrate reductase activity of free and immobilized cellsof Hapalosiphon sp. at 48h. FC -Free cells. IC- Immobilized cells

\begin{tabular}{|l|l|l|l|l|l|l|}
\hline \multirow{3}{*}{\begin{tabular}{c} 
Conditions \\
\cline { 2 - 7 }
\end{tabular}} & $\begin{array}{c}\text { Napalosiphon (without } \\
\text { Selenium) }\end{array}$ & $\begin{array}{c}\text { Hapalosiphon+200ppm } \\
\text { Selenium }\end{array}$ & $\begin{array}{c}\text { Hapalosiphon+250ppm } \\
\text { Selenium }\end{array}$ \\
\cline { 2 - 7 } & $\mathbf{F C} \pm$ SD & IC \pm SD & FC \pm SD & IC \pm SD & FC \pm SD & IC \pm SD \\
\hline Control & $2.385 \pm 0.13$ & $2.692 \pm 0.16$ & $2.846 \pm 0.17$ & $3.077 \pm 0.20$ & $1.529 \pm 0.05$ & $1.720 \pm 0.06$ \\
\hline 1\% oxalic acid & $2.077 \pm 0.10$ & $2.462 \pm 0.14$ & $2.320 \pm 0.13$ & $2.769 \pm 0.17$ & $1.431 \pm 0.05$ & $1.711 \pm 0.06$ \\
\hline 5\% oxalic acid & $2.920 \pm 0.23$ & $3.385 \pm 0.29$ & $3.240 \pm 0.22$ & $3.769 \pm 0.27$ & $2.769 \pm 0.14$ & $3.231 \pm 0.17$ \\
\hline $10 \%$ oxalic acid & $1.474 \pm 0.04$ & $1.632 \pm 0.06$ & $1.745 \pm 0.06$ & $1.920 \pm 0.08$ & $1.175 \pm 0.02$ & $1.317 \pm 0.02$ \\
\hline
\end{tabular}

Fig.1 Effect of selenium on growth of Hapalosiphon sp. in free and immobilized cells.

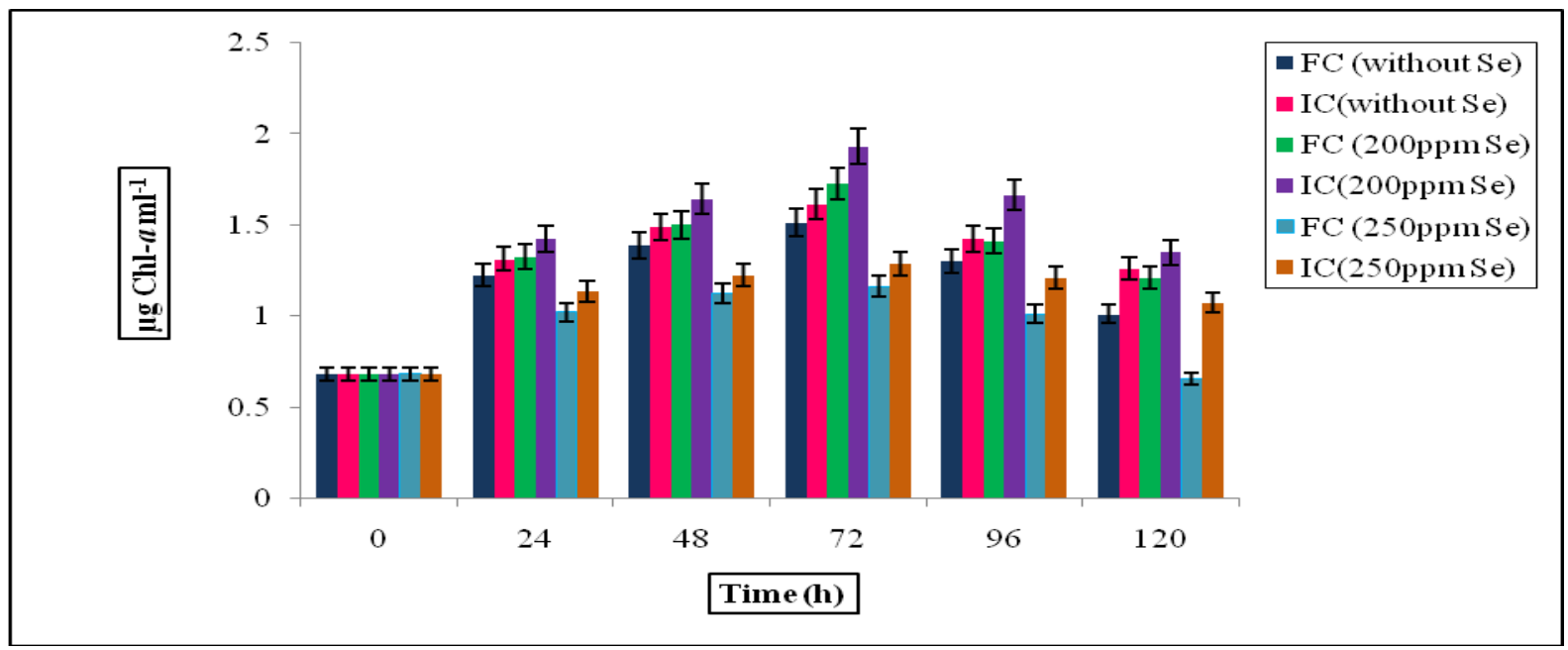

(Results mean $\pm \mathrm{SD}, \mathrm{n}=3$ ) 
Fig.2 Percentage increase in the growth of free and immobilized cells of Hapalosiphon in oxalic acid (5\%) at $72 \mathrm{~h}$.

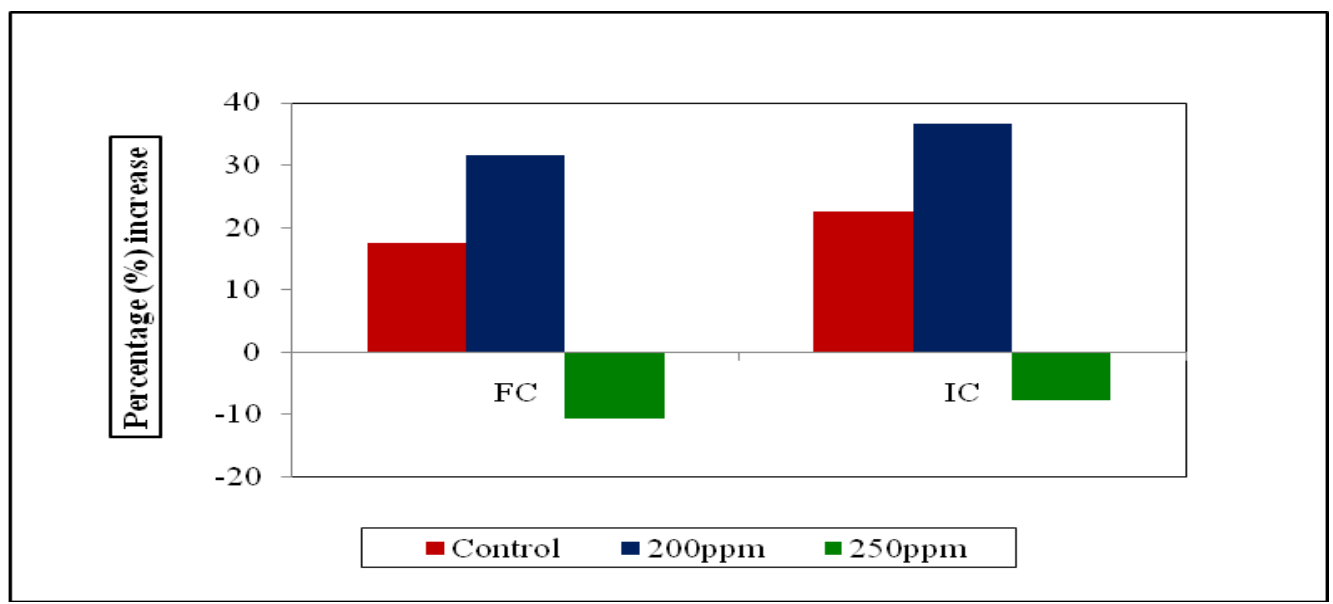

Fig.3 Effect of selenium on nitrate reductase activity of Hapalosiphon sp. in free and immobilized cells

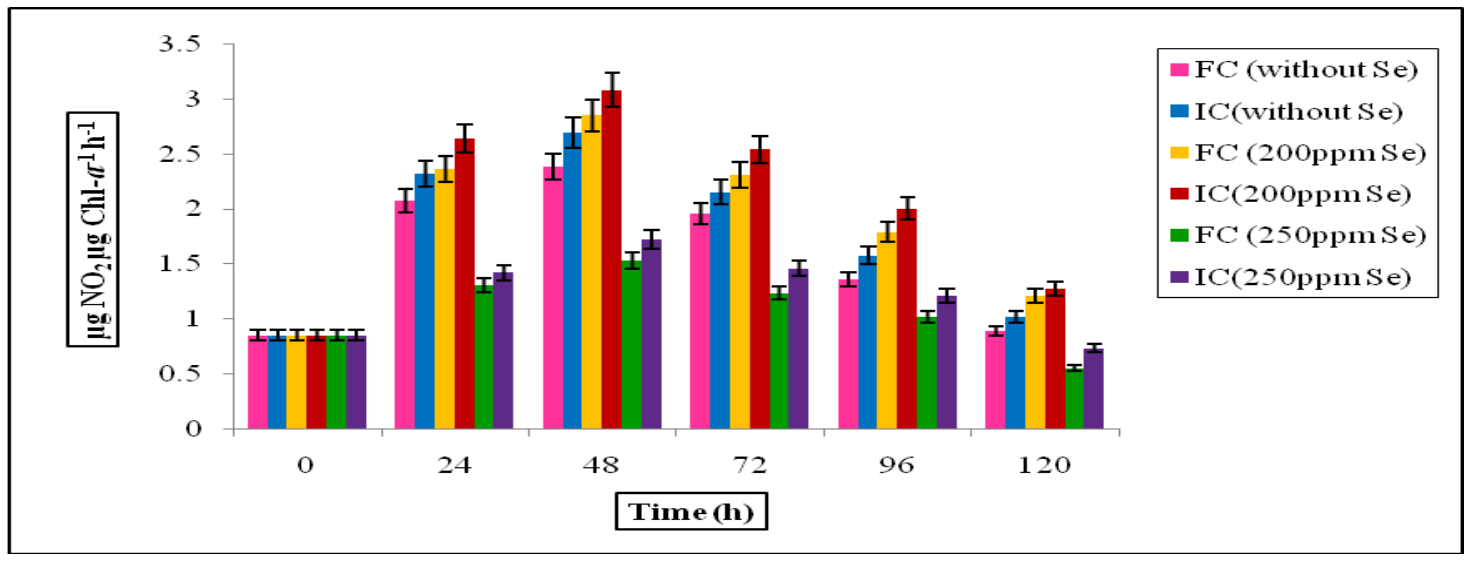

Fig.4 Percentage increase in the nitrate reductase activity of free and immobilized cells of Hapalosiphon in oxalic acid (5\%) at $48 \mathrm{~h}$.

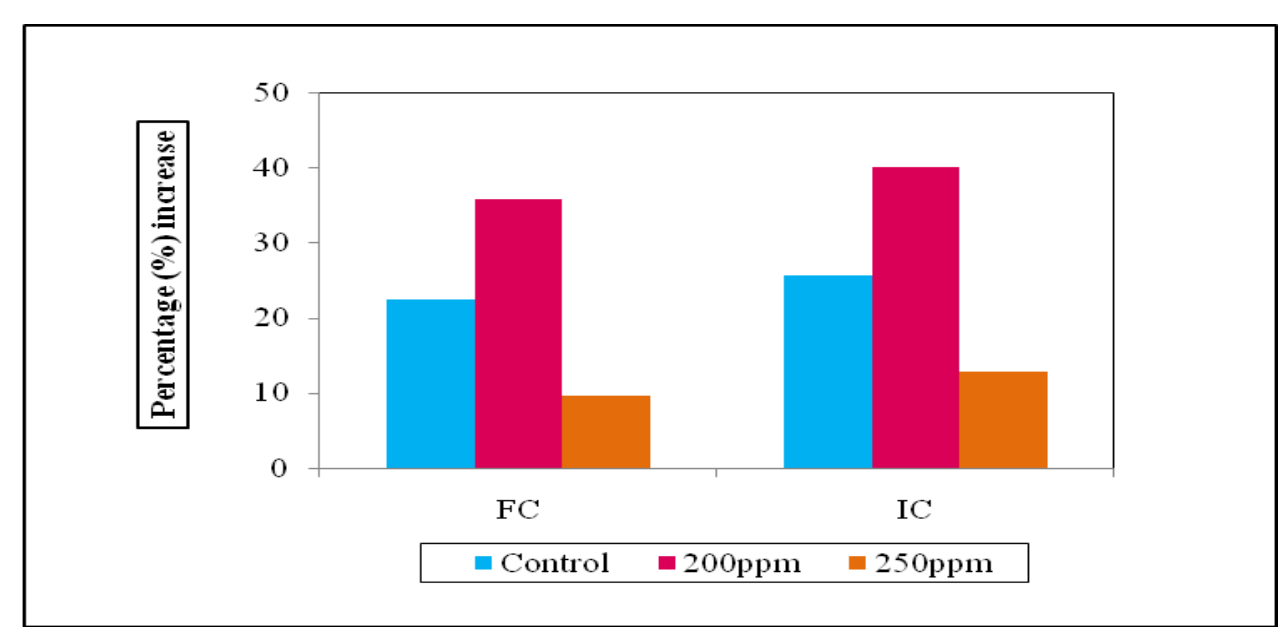


Basically, immobilization brings about increase in growth by producing direct contact between cell and medium, thus increasing the surface area available for various cellular reactions. On the other hand, the increase in nitrate reductase activity may be due to change in the cellular behavior by directly modifying the intrinsic characteristics of the culture as beads by forming a monolayer on the surface of the culture medium thus increasing not only surface area but also increasing availability of other important environmental parameters like light and oxygen concentration, (Banerjee and Mishra, 2002; Marsac and Houmard, 1993).

In addition, an interesting observation is that environmental factor like chelating agents at particular concentrations not only overcome the toxic effect of metal but also stimulate the growth and NR-activity of cyanobacteria. It is generally assumed that the chelators are required to maintain essential trace elements in solutions for the normal growth and enzyme activity.

Even in natural environment, extracellular exudates for cyanobacteria and other microorganisms help to maintain a balance of toxic and unwanted elements from entering the cells by entrapping them in the matrix. After death and decomposition of cyanobacteria; polysaccharides, polypeptides, lipids, mucilage, peptones and organic acids released in the medium and act as natural chelators, which bind the toxic metals, converting the metal to almost inactive and non-toxic forms (Ma et al., 1998). In this study a similar function of chelating agent i.e. oxalic acid, which are a group of biomolecules that can function as chelators of metals inside the cells, was noted for the Selenium, which was chelated in its presence, restoring and stimulating the growth and nitrate reductase activity. On the other hand, decrease in growth and enzyme activity with the addition of $5 \%$ oxalic acid in control cells (without added metal) is probably because upon entry within the cell it chelates and precipitates many essential nutrients needed for the growth and enzyme activity.

In conclusion, from the present study, it is concluded that under natural conditions cyanobacterium Hapalosiphon sp. which is generally present in the rice fields as a naturally immobilized sheath can tolerate higher level of selenium, and shows pronounced nitrate reductase activity in the presence of this toxic metal. Therefore they ensure the nitrogen supply to the rice plants via these organisms and maintain the nitrogen economy of paddy fields in spite of the presence of selenium metal. It is also points out to the fact that cyanobacterial addition to selenium contaminated sites is an effective, safe, cleaner and useful bioremediation processor the removal of selenium from the environment.

\section{Acknowledgement}

The authors are grateful to the Head, Department of Bioscience for necessary laboratory facilities.

\section{References}

Banerjee, M. and Mishra, S. 2002. Mitigating effect of immobilization on Aulosira fertilissima subjected to nickel and chromium stress. Bull. Bios., 43-46.

Banerjee, M. and Yadav, S. 2009. Cyanobacterial mitigation of lead toxicity. J. Pl. Sci. Res., 25(2): 231235.

Banerjee, M., Chouhan, R., Verma, V., and Gole, S. 2008. Bioremediation of Selenium by Cyanobacterium Hapalosiphon Sp. Biospectra, 3(2): 305-310.

Camm, E.L. and Stein, J.R. 1974. Some aspects of nitrogen metabolism of 
Nodularia spumigena (Cyanophyceae). Can. J. Bot., 52:719-726.

Chapman, P.M. 2000. Selenium-Fate and Effects in the aquatic environment. Proceedings of the $24^{\text {th }}$ Annual British Columbia Mine Reclamation Symposium in Williams Lake, B.C.148-159.

Chen, H. and Pan, S. 2005. Bioremediation potential of Spirulina: toxicity and biosorption studies of lead. J. Zhejiang Univ., SCI.6b. 171-174.

Chouhan, R. and Banerjee, M. 2010. Two cyanobacteria Hapalosiphon sp. and Gloeocapsa sp. in amelioration of selenium toxicity. J. Appl. Biosci., 36(2): 137-140.

Desikachary, T.V. 1959. Cyanophyta. Indian council of Agricultural Research, New Delhi.

Gadd, G.M. 2010. Metals, minerals and microbes: geomicrobiology and bioremediation. Microbiol., 156, 609643.

Geitler, L. 1932. Cyanophyceae In: Rabenhorst's Kryptogamen, - Flora. Akademischce Verlags-Gesellscaft, Leipzig Vol. 14.

Gilmour, C. and Riedel, G. 2009. Biogeochemistry of trace metals and metalloids. In Encyclopedia of Inland Waters, pp. 7-15. Edited by G. E. Likens. Amsterdam: Elsevier.

Gupta, R., Ahuya, P., Khjan, S., Saxena, R. K and Mohapatra, H. 2000. Microbial Biosorbents: Meeting challenges of heavy metal pollution in aqueous solutions. Curr. Sci., 78(8): 967-973.
Kretschmer, X.C., Meitzner, G., GardeaTorresdey, J.L. and Webb, R. 2003. Determination of $\mathrm{Cu}$ Environments in the Cyanobacterium Anabaena flosaquae by X-Ray Absorption Spectroscopy. Appl. Environ. Microbiol., 70(2): 771-780.

Kumar, A. and Kumar, H.D. 1980. Tungsten induced inactivation of molybdoenzymes in Anabaena. Biochem. Biophys. Acta., 613: 244-248.

Landa, E.R. 2005. Microbial biogeochemistry of uranium milltailings. Adv. Appl. Microbiol., 57, 113-130.

Ma, J.F., Hiradate, S., and Matsumoto, H. 1998. High aluminium resistance in buck wheat, II oxalic acid detoxifies aluminium internally. Plant Physiol., 117: 753-759.

Mackinney, G. 1941. Absorption of light by chlorophyll solution. J. Biol. Chem. 140: 315-322.

Marsac, D. T. and Houmard, J. 1993. Adaptation of cyanobacteria to environmental stimuli: New steps towards molecular mechanism. FEMS Microbiol. Rev., 104: 119-190.

Rippka, R., Neilson, R., Kuisawa, R. and Cohen, G.B. 1979. Nitrogen fixation by unicellular blue green algae. Arch. Microbiol., 76: 341.

Singh, S.P., Verma, S.K., Singh, R.K. and Pandey, P.K. 1989. Copper uptake by free and immobilized cyanobacterium. FEMS Microbiol. Lett., 60: 193-196.

Sparks, D.L. 2005. Toxic metals in the environment: the role of surfaces. Elements, 1: 193-196.

\section{How to cite this article:}

Rachana B. Chavan and Meenakshi B. Bhattacharjee. 2016. Role of Alginate and Oxalic acid in Ameliorating Se Toxicity in Hapalosiphon cyanobacterium. Int.J.Curr.Microbiol.App.Sci. 5(11): 132-139. doi: http://dx.doi.org/10.20546/ijcmas.2016.511.015 